\title{
WPS3609
}

Why Governments Should Stop Non-Social Subsidies:

Measuring Their Consequences for Rural Latin America

By

Ramón López

University of Maryland at College Park

(Tel.301-405-1281; Fax: 301-314-9091; email: rlopez@arec.umd.edu)

\begin{abstract}
The provision of public goods and the amelioration of market failure are the classical justifications for government intervention in the economy. In reality, (1) governments intervene in markets that are not affected by failure, and (2) a large share of the government resources is spent in private goods, not in public goods. In contrast to issue (1), issue (2) has received little attention in the literature, in spite of the potentially large efficiency and equity losses arising from misguided allocations of public expenditures. This paper empirically documents the size of (2) in the rural sector and investigates its consequences for rural development for ten Latin American countries over the 1985-2000 period. The econometric evidence suggests that the structure of public expenditures is an important factor of economic development in the rural sector, much greater than that of the level of public expenditures and of other factors on which the development literature has traditionally focused. Expanding total public expenditure in rural areas while maintaining the existing public expenditure composition prevailing in certain countries does little to promote agricultural income and reduce rural poverty. Spend ing a significant share of government resources in (non-social) subsidies causes less agriculture income, induces an excessive reliance of agriculture on land expansion and reduces the income of the rural poor.
\end{abstract}

World Bank Policy Research Working Paper 3609, May 2005

The Policy Research Working Paper Series disseminates the findings of work in progress to encourage the exchange of ideas about development issues. An objective of the series is to get the findings out quickly, even if the presentations are less than fully polished. The papers carry the names of the authors and should be cited accordingly. The findings, interpretations, and conclusions expressed in this paper are entirely those of the authors. They do not necessarily represent the view of the World Bank, its Executive Directors, or the countries they represent. Policy Research Working Papers are available online at http://econ.worldbank.org.

Excellent research assistance was provided by Denise Falck, Gregmar I. Galinato, and Carolina Handall. I would like to thank Daniel Lederman, Mark Wenner, and Bruce Gardner for comments and discussions on the issues of this paper. 


\section{Why Governments Should Stop Non-Social Subsidies: Measuring Their Consequences for Rural Latin America}

\section{Introduction}

The provision of public goods and the related issue of ameliorating the impact of market failure are the classical justifications for government intervention in the economy. In reality, governments often do not do a good job in fulfilling these roles: (1) they intervene in markets that cannot be even remotely considered affected by failure or imperfections, and (2) a large share of the financial, human and institutional public resources is spent in private goods (nonsocial subsidies), not on public goods.

Misguided public policies that interfere with essentially efficient markets have been for a long time a central concern to economists. The literature documenting and measuring the efficiency costs of market interferences for many commodities and many countries around the world is indeed massive. ${ }^{1}$ On the basis of these studies, international organizations as well as several other economic institutions have forcefully argued for the removal of government interference with markets for several decades.

The high degree of attention that the economics literature has given to issue (1) contrasts with the relatively little concern that issue (2) has generated. This despite the potentially large efficiency and equity losses arising from misguided allocations of public expenditures. This paper empirically documents the size of (2) in the rural sector and measures its consequences for rural development (per capita income, agricultural land intensity, and rural poverty) for ten Latin American countries over the period 1985-2000 using a newly assembled data set.

Diverting part of the government resources to spending in private goods means that government over-taxes the private sector, under-supplies public goods (includ ing expenditures in dealing with market failures), or both. ${ }^{2}$ Whatever the means used by the public sector to finance spending in private goods, efficiency losses associated with the inevitable distortions caused by raising more taxes than needed or by under-providing public goods are implied. For the empirical part of this paper, however, we assume that the total fiscal resources (financial, human,

\footnotetext{
${ }^{1}$ The book by Krueger, Schiff, and Valdés (1991) constitutes a distinguished example of the great effort spent by the profession in documenting and criticizing government interference with otherwise efficient markets.

${ }^{2}$ A third possibility is instead to increase public debt. Increasing government debt may over periods of time allow governments to spend large volumes of revenue on private goods without decreasing expenditures in public goods, while still keeping the tax burden low. But the debt mechanism is available mainly over the short run.
} 
and institutional) available for the rural sector are exogenous and fixed. This allows us to concentrate the empirical analysis on various forms of crowding out of expenditures on public goods within a fixed rural budget. For the sake of keeping the issues in perspective, however, the remainder of this introduction and the next section will retain a broader level of generality in this respect.

The under-provision of public goods may have serious negative consequences for the productivity of private investment, as public goods are important complementary assets with private capital. As we shall see below, non-social subsidies, often available only to selected individuals and firms, appear to contribute little to stimulate growth. Thus, the restricted supply of public goods (or higher taxes) necessary to finance spending in subsidies may involve a poor tradeoff as a policy to promote growth. A low supply of public goods means scarcity of human capital, $^{3}$ underinvestment in research and development (R\&D), less infrastructure, insufficient sanitary and environmental protection, etc. (World Bank, 2000). All these are important assets that contribute to increase the productivity of private investments. Hence their scarcity is likely to constitute an obstacle to economic expansion.

The biased structure of public expenditure allocation may have important social equity implications as well. For reasons to be discussed below, government expenditures in (non-social) subsidies and other private goods tend to be directed toward the wealthier segments of society and, at the same time, have little effect in promoting employment. The only significant assets of the poor are their labor force and, for the rural poor, their natural resources. The income of the poor is thus extremely dependent on their ability to enhance their human capital and to protect the natural assets, both important public or semi-public goods.

Over-taxation that spending in private goods may cause also has negative equity consequences. It is well known that in most developing countries the tax system is not progressive, especially because of its great reliance on indirect taxation and because of the prevalence of tax evasion. ${ }^{4}$ So the additional taxes needed to finance subsidies to selected

\footnotetext{
${ }^{3}$ Education and health care, though not pure public goods, have characteristics of public goods, especially in developing countries. Their positive externalities are well documented in the literature. The poor, who often constitute a large segment of the population in developing countries, are generally unable to finance even highly profitable investments in human capital due to imperfections of capital markets; so if governments do not intervene in some form, such investments are often not realized.

4 "Given the low importance of personal income taxes and property taxes in Latin American countries, the direct distributive leverage of the tax system in most countries should be expected to be very small or even negative" (World Bank, 2004, p. 254). According to the World Bank, while in developed countries income taxes and property
} 
individuals and firms are to a significant degree paid by the poor. In addition, the undersupply of public goods affects the welfare of the poor much more than the welfare of the wealthy.

Many empirical studies have measured the impact of specific public goods such as R\&D, rural roads, and other infrastructure on agriculture as well as on other sectors. ${ }^{5}$ What seems to be missing, however, is a broader approach that may permit evaluation of the impact of public goods vis-à-vis other types of government expenditures on efficiency and social equity. Without such a comparison, the conceptual and policy implications of findings pointing to the payoffs of certain specific public expenditures are in part overlooked.

At the policy level, there seems to be a degree of consensus regarding the importance of an adequate provision of public goods for economic expansion and social equity. However, the same lack of a clear conceptual framework and the general weakness of empirical studies due in part to such a conceptual deficit also mean a certain weakness in the policy recommendations. It is clearly a rather empty policy statement to advise governments to increase expenditures on education, health, roads, etc., without pinpointing the source of the low expenditures on such goods in the first place, and without indicating what expenditures to cut (or what taxes to raise) in the second place. ${ }^{6}$

Apart from affecting the rate of agricultural growth, the heavy emphasis of governments on subsidizing the wealthy is likely to affect the patterns of growth of agriculture. In particular, a hypothesis that we test here is that (non-social) subsidies tend to make agricultural growth much more dependent on land expansion than on intensification. In many countries, especially tropical ones, agricultural growth is linked to area expansion much more than to intensification ${ }^{7}$ This pattern of growth is often responsible for the large deforestation impacts attributed to agriculture by many studies (Barbier, 2004). It has been shown that when governments are prone to

taxes constitute more than $10.5 \%$ of GDP, in Latin America they comprise only $3.7 \%$ of GDP. Another study, by Chu, Davoodi, and Gupta (2000), corroborates this finding.

${ }^{5}$ See, for example, the survey by Alston et al. (2000) of studies documenting returns to agricultural R\&D and extension; Psacharopoulos (1994) for returns to education; and the World Bank (2000) for an extensive review of studies measuring returns to various other public goods.

${ }^{6}$ It can also be counterproductive because it may induce governments either to increase taxes, which, given the weaknesses of the tax system discussed earlier, may have negative efficiency and equity effects, or worse to create fiscal disequilibria that could over the intermediate run become very costly and cause an even greater undersupply of public goods (Argentina is probably an important recent example of the latter).

${ }^{7}$ Graham, Gauthier, and Mendonça de Barros (1987), for example, concluded that area expansion rather than yield increases accounts for practically all of the growth of Brazilian agriculture between 1950 and 1980. Similar findings are documented by López (1997) for Ghana. 
provide non-social subsidies, expanding farm size beyond optimal levels is a rational response by farmers signaling their disposition to offer bribes in exchange for subsidies (Bulte, Damania, and López, 2004). Land expansion is thus a vehicle to promote subsidies, and knowing that governments are prone to subsidize induces farmers to expand land area. That is, land expansion and subsidies are the cause and effect of each other.

In summary, this paper conceptually justifies and empirically tests three hypotheses: (i) that countries that, ceteris paribus, spend a greater share of rural public expenditures in private goods have lower agricultural per capita income than countries that spend more on rural public goods; (ii) that agriculture in these countries tends to be more dependent on the expansion of the land area rather than on intensification; and (iii) that rural poverty in these countries is worse.

To test these hypotheses we use a newly assembled data set for the period 1985-2000 for the rural sector for several countries in Latin America. These data consist of annual rural public expenditures collected using a consistent methodology across countries and over time. The high degree of detail of these data is sufficient to allow us to aggregate rural expenditures in public goods and in private goods.

The remainder of this paper is organized as follows. First we discuss general conceptual issues, in Section II. In Section III we present the empirical model. Section IV provides an overview of the data used. Section V presents the econometric results. Section VI concludes.

\section{Conceptual Issues}

The classification of public expenditures into public goods and private goods arises from the conceptual view that governments' primary responsibility is to, using use taxpayers' money, supply public goods, including goods and services that are undersupplied as a consequence of missing markets or of market imperfections. ${ }^{8}$ The importance of the public versus private good dichotomy is that while the public good tends to be complementary with private investment, the private good, as we shall see, tends to be a substitute for private investment.

Political motivation and the structure of public expenditures. The political motivation of the government to invest in public goods is fundamentally different than its motivation to do so in private goods, and such different motivations cause important socio-economic effects of the public/private good choice. By definition the benefits of public or semi-public goods tend to

\footnotetext{
${ }^{8}$ In practice, as we shall see, the distinction between public and private goods is not sharp. But by and large, more often than not, a reasonable separation between these goods is possible.
} 
disperse much more among the population than those of private goods. This implies that the political lobby targets private goods that wholly benefit particular lobby groups much more than they target public goods, of which the lobby group shares only a fraction of the benefits. The struggle by lobby groups to elicit subsidies from the government is often the ir prime motivation. It is well known that successful lobbies are typically constituted by small group s with a clear common interest and objectives (Olson, 1965). In addition, and most important, successful lobby groups often have enough financial means to bribe politicians and to contribute to their political campaigns, or they have enough social status to be able to affect public opinion through a variety of means. ${ }^{9}$

These requirements for constituting a successful lobby are often satisfied by economic elites and rarely by the poor. ${ }^{10}$ The implication is by now a stylized fact: Government expenditures in private goods go almost always to the wealthy and only very rarely to the poor. ${ }^{11}$ This is in sharp contrast with expenditures in public goods, which generally produce benefits that tend to disperse across all groups in society, poor and non-poor alike. The social equity effects of the composition of public expenditures are obvious: The greater the share of government expenditures in private goods, the worse, ceteris paribus, is income distribution and poverty. Because the structure of public expenditures tends to be more biased towards private goods when the economic power of the elites is in the first place already greater, such biased composition of public expenditures may be both cause and effect of poverty and social inequity.

The structure of public expenditures and economic efficiency. The public/private good dichotomy is grounded on another factor which has to do more directly with economic efficiency than with equity. Investment in public goods provides factors of production that are almost by definition rarely supplied by the private sector. For this reason one can reasonably expect that such investment will fill a vacuum that is not fulfilled by the private sector. As a consequence, a complementary relationship between private investments and public goods is likely to arise.

\footnotetext{
${ }^{9}$ Deacon (2002), among others, has empirically shown that less democratic governments (and in general those that give less opportunity to their citizenry to participate in decision making and that are therefore prone to lobby pressures from the wealthy) tend to provide a lower share of public expenditures on public goods, instead placing more emphasis on non-social subsidies.

${ }^{10}$ Sometimes organized workers, who are often not part of the wealthier segments of society, are able to also become powerful lobbies. However, the successful workers' lobbies rarely encompass the poor. Recently certain groups among the poor (some indigenous groups, grass-root organizations, etc.) have been able to become part of the lobby forces, but their capacity to effectively lobby governments tends to be limited by disadvantages in terms of group size, education, and other shortcomings.

${ }^{11}$ For an empirical illustration of this phenomenon see Calmon (2004) with dramatic evidence for Brazil.
} 
Government expenditures in private goods (non-social subsidies), by contrast, often finance assets that could equally well be financed directly by private entrepreneurs. Even more important, as argued above these government subsidies go to the wealthy, who already face generally no constraints to invest at optimal levels (who are likely to face no liquidity constraints or other types of market imperfections). As shown below, the effect of these subsid ies is almost always detrimental for economic efficiency and, far from contributing to promote private investment, the subsidies tend to crowd it out and to increase the consumption of the wealthy instead. $^{12}$

Thus, we have another important contrast that justifies the emphasis on the public/private goods dichotomy: While increasing public goods is likely to promote economic growth directly (as factors of production) and indirectly (through its positive effect on private investment), increasing subsidies is more often than not deleterious for growth and private investment.

Crowding-out and agricultural performance. Government provision of private goods or subsidies causes three forms of crowding-out with negative efficiency and equity effects:

(i) Subsidies crowd out the supply of public goods through the government budget, human, and institutional constraints. The budget crowding-out is obvious: government-provided subsidies compete with the provision of public goods, not only for government's financial resources but also for other public resources that also tend to be scarce. The administration of subsidy programs often absorbs a large share of the limited availability of the government's human capital. Scarce institutional capital is also usually preferentially allocated to subsidy programs.

Governments forego investments in public goods that, according to many studies, have extremely large rates of return. The survey by Alston et al. (2000), for example, reviews hundreds of studies around the world estimating rates of return to agriculture R\&D revealing extremely high and non-declining rates. Psacharopoulos's (1994) survey does the same for studies measuring returns to education over many countries, also showing very high rates. Also, a study by Fan, Hazell, and Thorat (2000) found unusually high returns to a variety of public infrastructure investment in agriculture in India and China. The World Bank (2000) has gathered evidence also pointing to very high rates of return to certain investments in protecting the

\footnotetext{
${ }^{12}$ Subsidies may, however, be directed in some cases to mitigate market imperfections and externalities that otherwis e may prevent even wealthy entrepreneurs from optimally investing. The evidence available, however, seems to indicate that subsidies that can be justified in this way are rarely implemented.
} 
environment. Thus the persistence of such unusually large rates of return suggests that underinvestment in public goods is likely to have large negative effects on per capita income. This conclusion is reinforced by further empirical evidence showing that subsidies have low or even negative economic rates of return and that they crowd out private investment. We turn to these issues next.

(ii) Subsidies may directly crowd out private investments. Consider what is often regarded as a "desirable" subsidy: the government offers to pay a portion of the cost for a particular investment. ${ }^{13}$ The subsidy is of course rationed as the funds are normally less than the demand. Assume for simplicity that their allocation among producers is transparent, not subject to corruption. Consider an investor who is able to extract a profitable return out of an investment (even in the absence of the subsidy) who potentially may qualify for the subsidy but who does not obtain the subsidy. The producer may go ahead with the investment (without getting the subsidy) anyway, since it is a profitable one. Alternatively, she/he may opt to postpone the investment and to try again the following year in the hope of then getting the subsidy. If the expected value of the subsidy is sufficiently large to compensate the foregone profits of one year, the producer may decide to delay the investment. ${ }^{14}$ Thus, investments that are privately (and socially) profitable may be postponed as a consequence of the existence of the subsidy.

Among the investors who actually get the subsidy there are two types: those who would have implemented the investment anyway and those who otherwise would not have (because they would not be able to get high enough returns). For the former the subsidy is ineffective. For the latter the subsidy is effective insofar as it causes them to invest, but, in the absence of positive externalities associated with the investment, they do so at a low social return. Thus, the subsidy scheme does two things: (i) it increases consumption rather than investment by producers who are able to obtain the subsidy but who would have invested anyway, and (ii) it reallocates investment from those producers who potentially could have gotten high rates of return but who did not obtain the subsidy (and who decide to postpone the investment, expecting

\footnotetext{
${ }^{13}$ This example is based on an actual irrigation-drainage public subsidy scheme for "small" projects (subsidy amount up to US $\$ 275,000$ per producer) in Chile that cost the government about US\$30 million per year, using parameters obtained from the program.

${ }^{14}$ Suppose the subsidy is 50\% (the Chilean subsidy pays between $25 \%$ and $75 \%$ of the total investment) of the value of the investment cost and that the rate of return per annum of the investment is quite high, 20\%. Assume further that the producer estimates that the probability of getting the subsidy the following year is 0.5 (in the Chile example, about $45 \%$ of the proposals are funded). If the producer is risk-neutral, he/she will decide to delay the investment for one year.
} 
to get the subsidy in the future) to producers who obtain a low social return but invest only because they are able to access the subsidy. The net effect on total investment is ambiguous, but the efficiency impact is negative as a consequence of effect (ii).

The above example is not just a curiosity. That subsidies, at least in the form in which they are usually allocated, do not generally promote investment has been shown by several empirical studies in various countries. Empirical studies using detailed firm-level data by Bregman, Fuss, and Regev (1999) for Israel, Fakin (1995) for Poland, Lee (1996) for Korea, Bergstrom (1998) for Sweden, Estache and Gaspar (1995) for Brazil, Harris (1991) for Ireland, and several others have shown that subsidies and corporate tax concessions targeted to specific firms are at best ineffective in promoting investment and technological adoption and, in some instances, even counterproductive. Crowding-out of private investment as a consequence of the subsidies occurs.

(iii) Subsidies may indirectly crowd out private investment in the intermediate run. The third type of crowding-out of private investment as a result of public expend iture biases toward subsidies is long-run in nature. The low stocks of public goods caused by continuous underinvestment in public goods causes low productivity of private investments over the long run. This, in turn, is translated into slower investment and slower productivity growth over the long run (World Bank. 2000).

The structure of public expenditure and rural poverty. Public goods affect rural poverty through direct effects and through indirect effects:

(i) Direct effects. Important components of rural public goods are human capital and investment in the protection of natural resources and the environment. Human capital is the main productive asset for most poor. However, as a consequence of credit and other market failures they are not in general able to fully finance investments in human capital, regardless of how high the rate of return to these investments might be (World Bank, 2000). They are, therefore, largely dependent on the public sector as a source of financing for these investments. On the other hand, the rural poor are also highly dependent on natural resources as a source of subsistence (Barbier, 2004). The price of resource degradation is often disproportionately paid by the rural poor. Increasing investment to protect natural resources and to mitigate environmental externalities is, therefore, vital to reducing rural poverty. 
(ii) Indirect effects. As discussed earlier, an adequate stock of rural public goods contributes to sustain growth for agriculture and related rural industries. In general much of the rural industry linked to agriculture is highly intensive in unskilled labor (Lanjouw and lanjouw, 1995).

Moreover, it appears that the rural sector in many developing countries is important enough within the broader unskilled labor market to significantly affect the real wages for unskilled workers even at a national level. Thus a dynamic rural productive sector is a vital source of employment for unskilled workers as it may play a role in supporting higher real wages. To the extent that most poor are unskilled workers, these effects may be important in reducing poverty.

\section{The Model}

The agriculture per capita value-added function. The approach is to specify a reducedform model that explains agricultural GDP per capita as a function of variables that are exogenous to agriculture as well as of policy variables. We start with specifying a production function,

$$
Q=F(L, K, X ; A)
$$

where $\mathrm{Q}$ is agriculture output, $\mathrm{L}$ is labor used in the sector, $\mathrm{K}$ is a vector of primary factors of production owned by farmers, $\mathrm{X}$ is a vector of purchased inputs, and $\mathrm{A}$ is a productivity index. We assume that $\mathrm{F}(\mathrm{)}$ ) is concave in $\mathrm{K}, \mathrm{L}$, and $\mathrm{X}$, and that it is subject to constant returns to scale; that is, $\mathrm{F}\left(\mathrm{)}\right.$ is homogenous of degree one in $\mathrm{L}, \mathrm{K}$, and $\mathrm{X} .{ }^{15}$

Agriculture value added or GDP is defined as the returns to primary factors, K and L. Thus,

$$
G(p, v ; K, L ; A) \equiv \max _{X}\{p F(L, K, X ; A)-v X\},
$$

where G( ) is agriculture GDP, $p$ is output price, and $v$ is a vector of purchased input prices. The function $\mathrm{G}(\mathrm{)})$ is a (dual) revenue or value added function and must satisfy certain conditions. The most important, from our point of view, is that, apart from being increasing and concave in $\mathrm{L}$ and $\mathrm{K}$, the agricultural value added function is also homogenous of degree one in $\mathrm{K}$ and $\mathrm{L}$. This follows directly from the constant returns to scale assumption. We can thus express per capita agriculture GDP as

\footnotetext{
${ }^{15}$ The assumption of constant returns to scale in agriculture has not often been rejected by empirical studies using farm household data. See, for example, López and Valdés (2000), who provide estimates for five countries in Latin America.
} 


$$
\bar{g}(p, v ; k ; A) \equiv \frac{G(p, v ; K, L ; A)}{L} .
$$

Per capita GDP is a function of output and purchased input prices, and the per capita values of the farmer's owned assets, $\mathrm{k}$, as well as of the productivity factor, A. It is increasing in $\mathrm{p}, \mathrm{k}$, and $\mathrm{A}$, and decreasing in $\mathrm{v}$. The remainder of this section is devoted to the estimation strategy of the per capita agricultural GDP function, $\bar{g}(p, v ; k ; A)$.

We postulate that output and purchased input prices are determined by world prices, domestic government policies (including trade policy, subsidies, etc.), and the performance of the non-agriculture economy, which may also play a role in affecting prices of non-traded commodities. That is,

$$
p=\phi\left(p^{*}, H, Y\right) ; \quad v=\psi\left(v^{*}, H, Y\right),
$$

where a star indicates world prices, $\mathrm{H}$ stands for a vector of government policies affecting domestic prices, and Y reflects conditions in sectors other than agriculture but ones that could affect prices relevant to agriculture. The variables $p^{*}, \mathrm{H}$, and Y are all subject to change over time as world market conditions, policies, and non-agricultural growth conditions vary.

The variable $\mathrm{A}$ is also endogenous and affected by variables exogenous to the farmer, including domestic market prices and government policies,

$$
A=A(H, p, v) \text {. }
$$

The level of A is postulated to be affected primarily by government policies, particularly public expenditures in public goods such as R\&D, extension, and education. It can also be affected by other market conditions that affect the profitability of adopting new technologies, represented by $\mathrm{p}$ and $\mathrm{v}$, as well as by k. Similarly, the conditions of the non-agriculture economy play a role on agriculture through the market effects associated with demand conditions for the commodities and inputs relevant to agriculture.

Combining (4) and (5) we obtain a reduced-form function for A,

$$
A=\bar{\psi}\left(p^{*}, v^{*}, H, Y\right) .
$$

We can disaggregate the vector $\mathrm{H}$ into $\mathrm{T}$ (trade policies), $\mathrm{E}$ (per capita total government expenditures in the sector), and $\mathrm{S}$ (the share of government subsidies in the total expenditures in the sector). We note that $\mathrm{S}$ includes both the direct non-social transfers as well as subsidies that 
take place via markets that demand government outlays (credit subsidies, deficiency payments, stabilization payments, etc.). Thus, we can write

$$
A=\psi\left(p^{*}, v^{*}, T, E, S, Y\right) .
$$

We expect that $\mathrm{A}$ is non-decreasing in $p^{*}, E$, and $Y$ and decreasing in $v^{*}$. The effect of $\mathrm{S}$ on $\mathrm{A}$ is, according to our previous discussion, non-positive. The variable $\mathrm{T}$ is defined as an index of trade openness. We expect that in countries that have used trade protection to discriminate against agriculture, as have most countries in Latin America, the effect of $\mathrm{T}$ on $\mathrm{A}$ is nonnegative.

Using (4), (5), and (7) in (3), we have now a specification for a reduced form for the per capita agricultural GDP function,

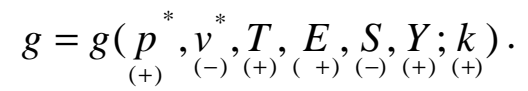

The signs underneath the variables indicate the expected effects of the various exogenous variables on the reduced-form per capita GDP. The sign pattern in (8) follows straightforwardly from the sign pattern of the structural GDP function, $\bar{g}(\mathrm{)}$, and from the signs of the effects of the exogenous variables on $\mathrm{k}$ and A pointed out earlier. Equation (8) is the basis for the specification of the estimating model of per capita agricultural GDP.

Econometric estimation of the per capita GDP function. Consider the following benchmark econometric specification:

$$
g_{i t}=\alpha_{1} L\left[E_{i t}\right]+\alpha_{2} L\left[S_{i t}\right]+\alpha_{3} L\left[T_{i t}\right]+\alpha_{4} L\left[Y_{i t}\right]+\alpha_{5} k_{i t}+\mu_{i}+\omega_{t}+\varepsilon_{i t},
$$

where $g_{i t}$ is the log of per capita agricultural GDP in country $i$ at year t, L are lag operators, and $E_{i t}$ is total government-provided services to rural areas in country $\mathrm{i}$ and year $\mathrm{t}$ $S_{i t}$ is the share of subsidies or private goods in $E_{i t}$ $T_{i t}$ is an index of trade policy openness in country $\mathrm{i}$ at time $\mathrm{t}$ $Y_{i t}$ is a measure of per capita non-agricultural GDP in country $\mathrm{i}$ at $\mathrm{t}$ $\mu_{i}$ is either a fixed country effect or, alternatively, a random country disturbance $\omega_{t}$ is a common time effect $\varepsilon_{i t}$ is a random, independently distributed disturbance with mean 0 and variance $\sigma^{2}$. 
We alternatively allow for a dynamic model where the lagged dependent variable is included as an additional explanatory variable $\left(g_{i t-1}\right)$ in (9). As we discuss below, this requires a more complex method of estimation to obtain consistent estimates with limited sample size (Arellano and Bond, 1991). ${ }^{16}$ Moreover, this generalization of the model does involve tradeoffs in terms of the efficiency of the estimates (more on this below). We estimate agricultural GDP per hectare using the same right-hand-side variables as in (9). Alternatively, we use agricultural GDP per hectare instead of agricultural per capita GDP as the dependent variable. In this case the variable $E_{i j}$ is normalized by agricultural land area instead of rural population.

Several important additional comments about (9) are in order:

(i) World prices. It is difficult to construct an appropriate price index for each country. As a proxy we use annual dummies $\left(\omega_{t}\right)$ that are supposed to capture international shocks, including world price changes that may affect the countries in the sample.

(ii) Unobserved country characteristics. There are many country-specific factors such as climate, land quality, institutions, etc., that may affect GDP but that we do not explicitly control for. These omitted variables may bias the coefficient estimated if they correlate with the explanatory variables, or at least affect the efficiency of the estimation. The role of $\mu_{i}$ is to control for such omitted variables as country-fixed effects or, alternatively, as random effects.

(iii) Government expenditures. While the vast majority of the government expenditures are current expenditures, a portion of them are investments that accumulate over time as capital goods. To control for this we experimented allowing both current and lagged values of $\mathrm{E}$ to influence current GDP levels. The same approach was used for the variable S.

(iv) Simultaneous equation biases. Public expenditures in agriculture may be affected by the performance of agriculture. This potentially causes simultaneity biases in the estimated coefficient of Eand S. We thus use lagged values of $\mathrm{E}$ and $\mathrm{S}$ as instruments when we estimate the regressions with the annual data. Similarly, the relationship between agriculture and nonagriculture income is likely to be simultaneous rather than unidirectional. This may potentially bias the estimates of the effect of $\mathrm{Y}$ in (9). To diminish the risk of such biases we use instruments in such a way that predicted rather than actual values of $Y$ are used in estimating (9). In the

\footnotetext{
${ }^{16}$ In this case a generalized method of moments (GMM) estimation is used. This means that the lag operators are no longer needed as the GMM approach uses the lag values of the variables as instruments in a systematic way.
} 
dynamic model, the GMM allows for a more comprehensive and systematic use of instruments (Greene, 2003).

(v) Agricultural primary factors. The vector $\mathrm{k}$ should in principle include per capita agricultural capital and agricultural land area. However, though for an individual farmer the land area may be part of his/her optimizing behavior, for the economy as a whole it may in the short run be fixed and in the long run greatly affected by government policy. Expanding the agricultural land area, especially in countries with remaining frontier areas, can be considered to be at least in part a government-controlled policy. If we assume that it is fully an endogenous variable there would be no reason to explicitly include it in the reduced-form specification (9). If, however, land is in part exogenous to the sector, then one needs to use it as an additional explanatory variable. We thus estimate two versions of (9): One that includes land area (through instruments to allow for its possibly endogenous component) as an additional explanatory variable, and another that does not. With respect to the other primary factor, we do not have data for agricultural capital, so we are forced to use the remaining explanatory variables in the reduced-form (9) as proxies. It may not be unreasonable to assume that agricultural capital is correlated with these variables, which may affect the profitability of capital in an important way. The interpretation of the coefficients of the other explanatory variables is, therefore, that they encompass the full effect of such variables, including the effects through $\mathrm{k} .^{17}$

Estimating the determinants of agricultural land area. It follows quite naturally from the previous discussion that we can postulate the following relationship, land $_{i t}=\gamma_{1} L\left[E_{i t}\right]+\gamma_{2} L\left[S_{i t}\right]+\gamma_{3} L\left[T_{i t}\right]+\gamma_{4} L\left[Y_{i t}\right]+\eta_{i}+\vartheta_{i t}$, where $\eta_{i}$ is a random or, alternatively, fixed effect, and $\vartheta_{i t}$ is a random disturbance with the usual desirable distribution properties.

Estimating rural poverty. It is postulated that rural poverty is affected by government policies and other exogenous factors through direct and indirect channels. Government expenditures in rural areas are likely to affect rural poverty directly through social expenditures that target the poor. In addition, government expenditures in rural infrastructure provide employment to part of the rural poor, thus contributing to reduce poverty. Trade policy may also have direct poverty effects by affecting domestic prices of food necessities and other

\footnotetext{
${ }^{17}$ That is, we assume that $k=\Omega\left(p^{*}, v^{*}, T, E, S, Y\right)$, where $\Omega$ is a real value function.
} 
commodities important to the poor. Also it may affect the incentives to production of commodities mostly produced by the poor vis-à-vis those produced by the non-poor. These policies also indirectly affect the rural poor if they have an impact on the performance of the agricultural sector. Finally, the rural poor may also be affected by the non-rural sectors of the economy through migration and remittances, and by affecting real wages in the rural areas.

We estimate variants of the following poverty equation,

$$
\operatorname{pov}_{i t}=\beta_{1} L\left[g_{i t}\right]+\beta_{2} L\left[Y_{i t}\right]+\beta_{3} L\left[E_{i t}\right]+\beta_{4} L\left[S_{i t}\right]+\beta_{5} L\left[T_{i t}\right]+\xi_{i}+\tau_{i t},
$$

where $\xi_{i}$ is a random country effect and $\tau_{i t}$ is a random disturbance. We expect the effects of $\mathrm{g}$, $\mathrm{E}$, and $\mathrm{Y}$ on poverty to be non-positive while the impact of $\mathrm{T}$ to be ambiguous and, according to the discussion in the previous section, the effect of $S$ to be positive. As in the case of the GDP equation, we tried various lag structures to capture for cumulative effects of the explanatory variable E over time as well as other instruments. The most popular measure of poverty is the head count ratio. However, head count measures may be quite heterogeneous as the definition of poverty lines tends to differ quite considerably across countries and over time. We use per capita income of the poorest two quintiles as a proxy for the variable $p o v_{i t}$.

\section{The Data}

In this section we examine a new data set for rural public expenditures for ten countries in Latin America recently assembled by the FAO regional office for Latin America and the Caribbean with the support of the World Bank and others. The annual data for the ten countries cover the period 1985-2000. ${ }^{18}$ An advantage of this data is that it is quite disaggregated while at the same time it has been measured using a reasonably consistent methodology across countries and over time. In addition the public expenditure data as provided is comprehensive, covering the vast majority of the items in which the public sector spends money in the rural areas. The level of detail of the data allows us to obtain a fairly accurate measure of the evolution of the level and composition of government expenditures in rural areas over the period.

The data for public expenditures in the rural sector cover all rural expenditures, including expenditures for agriculture as well as rural infrastructure, animal and plant sanitary protection, environmental expenditures, and social services to rural areas. The latter group covers

\footnotetext{
${ }^{18}$ The countries for which the data covers the full period are Costa Rica, Dominican Republic, Ecuador, Honduras, Jamaica, Panama, Paraguay, Peru, Uruguay, and Venezuela. For a detailed description of the data see Kerrigan (2001).
} 
expenditures in rural education, health, and other social sectors. All in all, rural public expenditures are disaggregated into 12 categories. The expenditure groups (including in brackets their respective average country share in total public expenditures for the year 1995) are the following: marketing assistance (28), irrigation (7.7), technological generation and transfers (4.7), soil conservation (1.2), forest promotion (0.09), plant and animal sanitation(4.2), communications and information (1.6), "focalized" expenditures directed to particular commodities (4.9), integral rural development (IRD) (4.1), rural public infrastructure (16.3), rural education, health, and other social services (25.5), and others (1.7).

To allocate the above expenditures into private versus public goods we first account for items that clearly fall into one or the other category. Next we deal with those categories that fall into a gray area where it is difficult to determine a priori whether they correspond to public or private goods. In these cases we have looked into more detailed components falling into these categories in the various country statistics available. This allowed us to obtain an educated guess as to what proportion of these expenditure items should be approximately allocated to public or private goods. Finally there are some minor items for which we were not even able to have a reasonable guess. In the latter cases we simply use a 50-50 rule.

Among the items that clearly qualify as public goods are technology generation and transfers, soil conservation, plant and animal sanitary protection, communications and information services, rural roads, and social services (public education, health, and anti-poverty programs). The above expenditures were classified as public goods, because they increase the supply of services that generate important positive externalities (technology generation and diffusion, soil conservation, plant and animal sanitation), were expenditures directed to at least in part palliate the impact of poverty (public education, health, and social programs), which can be regarded as a public "bad", and expenditures such as communication infrastructure and public roads that may roughly satisfy both criteria for pure public goods (non-excludability and nonrivalry).

Items that were considered private goods are commodity-specific or focalized expenditures, marketing promotion (excluding expenditures in communications and market information that are among the public goods items), and irrigation expenditures. An important portion of "market promotion" includes direct subsidies and credit subsidies to mostly well-off producers. Similarly, most of the irrigation services are completely or almost completely 
subsidized and benefit non-poor farmers. ${ }^{19}$ The third group (the gray group) includes the categories of forest promotion, IRD programs, and "others". Among the se items, a high proportion of the forest promotion expenditures were in the end allocated to public goods while a smaller fraction of IRD were considered to qualify as public goods. An important portion of tree planting expenditures is allocated to eroded areas, thus inducing positive externalities by protecting soils, contributing to the regulation of water regimes, etc. IRD expenditures are mostly subsidies to promote particular patterns of agricultural expansion that the planners desire. As such, a high portion of them do not qualify as public goods. ${ }^{20}$

Table 1 provides an overview of the total public expenditures in rural areas and its public good/private good distribution for the ten countries studied using average annual values for the 1985-2000 period. On average, more than $54 \%$ of the total government expenditures in rural areas were spent in private goods, while only $45 \%$ was spent in public goods. The average country in the sample spent about US\$214 million (2000 dollars) per annum in the rural sector, of which only $\$ 96$ million corresponded to public goods and $\$ 116$ million to private goods. This large allocation of public monies to private goods may suggest a significant degree of waste. At the same time it provides an indication of the importance of analyzing the impact of such an unbalanced allocation of public resources especially on economic performance and social equity. Even using a much weaker criterion for defining public good items (i.e., classifying all gray area expenditures as public goods and also allocating $50 \%$ of irrigation expenditures to such category), the average share of subsidies for the sample would still be a high value, about $48 \%$.

Total rural expenditures showed some real increases in several countries over time, especially in the period 1995-2000, a period in which they increased an average of almost $20 \%$ per country (from $\$ 177$ to $\$ 215$ million per country per year). But there is a dramatic variability across countries in this respect. The structure of government expenditures changed quite

\footnotetext{
${ }^{19}$ One may argue that classifying irrigation expenditures as private goods while other public infrastructure such as roads, bridges, etc., as public goods may appear as arbitrary. However, unlike other forms of public infrastructure, irrigation projects are targeted to a limited number of farmers (who usually pay little if at all for the water service), excluding everyone else from directly benefiting from the irrigation investment. In addition, irrigation water generally does not satisfy the indivisibility criterion of a public good; a farmer's consumption of irrigation water directly diminishes the availability for other farmers of using it. The only remaining question is whether or not the government irrigation investment helps to solve a market failure, which in general is not the case except for rare situations where the irrigation project serves poor farmers who may be affected by credit market failure.

${ }^{20}$ As reported in the next section, given the inevitable divergent views about the classification of some items into one or the other category, we did perform some limited sensitivity analysis to check for the robustness of the results to the classification criteria.
} 
significantly over the period. The average per country share of subsidies in total expenditures substantially declined, particularly over the last five years of the period. The average share of subsidies steadily fell from $60 \%$ in $1985-90$ to $58 \%$ in $1990-94$, and to $44 \%$ in $1995-2000$. Moreover, in practically all countries the proportion of subsidies in total government expenditures decreased or remained stable, the exceptions being Ecuador and Paraguay. The structure of public expenditures, not surprisingly, varies a lot across countries. Moreover it also exhibits a meaningful and large variability within countries over time. These large and seemingly meaningful variances are extremely important features which allow us to appropriately use panel data econo metrics, including fixed effects methods (Nerlove, 2002).

Turning to the remaining variables used, the indicator of trade openness is intended to measure the degree of openness of trade policy rather than trade volumes. Large countries (population and area wise) inherently tend to trade less than small countries, as they are naturally more self-sufficient, regardless of trade policy. If we want to use trade (imports plus exports) over GDP as a proxy for trade policy we must, therefore, normalize for country size and other structural characteristics (access to sea ports, oil wealth, etc.) that may affect the natural tendency of countries to trade. We normalize trade flows following a methodology used by Pritchett (1996), which consists in controlling for countries' geographic size, population, per capita income and other non-policy variables that are likely to affect the volume of trade. The index can be interpreted as an indicator of a country's trade policy openness with respect to the norm. $^{21}$

The data of agricultural land area per country over time is obtained from FAO sources, and the per capita non-rural income is estimated from national account data. Finally, since no data for agricultural labor exist, we use the total rural labor force as a proxy for L. Summary statistics for all the data used are provided in the appendix.

\section{The Results}

We estimate the reduced-form for per capita agricultural GDP using various methods of estimations and aggregating the data in several alternative ways. Our interest is primarily in probing the robustness of the estimated coefficients. We present estimates using three specifications: (1) regressions using country data aggregated for relatively long periods of time

\footnotetext{
21 The actual cross-country regressions used to estimate the norm included more than 120 countries. Details about the methodology used are available fro $m$ the author.
} 
("long-run" estimates); (2) static estimates obtained using annual data with various specifications for the lag operators; and (3) dynamic estimates, also using annual data.

"Long-run" estimates. An attractive feature of (1) is that it is consistent with the fact that much of the effects of the independent variables upon per capita agriculture GDP are likely to be embodied through processes that may take considerably more than one year to have an effect. Working with several year averages instead of annual data might help in elucidating what can be considered long-run effects. A drawback of the approach is that one loses degrees of freedom by reducing the number of observations. Alternatively, we used 3 or 5 year simple averages. ${ }^{22}$ In general the absolute values of the coefficients tend to be higher when 5-year averages are used, but their signs and degree of significance change very little.

Table 2 provides the Random Effects (RE) and Fixed Effects (FE) estimators of the per capita agricultural GDP regressions using 5-year simple averages as units of observation. The most important message emerging from all these estimates (as well as from the several alternative specifications used that we do not report here) is that while government expenditures have a positive and highly significant effect on agriculture per capita income, the structure or composition of such expenditures is quantitatively much more important and also of great statistical significance. In fact, the results show that increasing the share of (non-social) subsidies keeping the total public expenditures constant has a large negative impact on agricultural per capita GDP. According to the estimates, a reallocation of just $10 \%$ of the subsidy expenditures to supplying public goods instead may cause an increase in per capita agriculture income of about $2.3 \%$. And this is obtained without increasing the total government expenditures. ${ }^{23}$ By contrast, increasing government expenditures without altering their composition is much less effective in raising per capita agriculture incomes: A $10 \%$ expansion of government outlays causes on average only a $0.6 \%$ increase of agriculture income.

In 1996-2000, the $50 \%$ of the countries spending the least in rural areas spent about $\$ 35$ per capita, while the $50 \%$ spending the most spent about $\$ 74$ per capita. Thus, if the average country in the bottom half increased its per capita outlays to levels comparable to the average country in the top half, per capita agricultural GDP in that country could increase by more than

\footnotetext{
${ }^{22} \mathrm{We}$ also use moving averages.

${ }^{23}$ It is important to emphasize that this result is purely a composition effect under the assumption that the efficiency in use of resources in public goods (which several analysts have judged to be low) remains unchanged. Of course if the efficiency of public good programs increases, the change in the composition of public expenditures would have an even greater impact.
} 
$3 \%$. With respect to the share of subsidies, in 1996-2000 it ranged from approximately $30 \%$ on average for the bottom half of the countries to $65 \%$ for the top half. This means that if an average country in the top half could readjust its public expenditure share to the level of the average country in the bottom half, its per capita agricultural GDP might increase, ceteris paribus, by $12.5 \%$.

The results confirm the positive role of trade liberalization on agriculture income. This reflects the fact that agriculture is still discriminated against through protective trade policies. An opening up of trade policies consequently is not only good for overall economic efficiency but also for agriculture income. The marginal effect of the trade openness index on agricultural per capita income is about 0.002 and statistically significant. Moreover, this estimate is remarkably stable and robust to changes of specification. To get an idea of the meaning of this number it is useful to indicate that the trade openness index for the period for the most open country within the sample (Costa Rica) is about 60 points higher than that of the country that is least open (Uruguay). This means that if Uruguay had been as open as Costa Rica over the period, its per capita agricultural income would have been about $0.12 \%$ higher. Thus, though the effect of trade openness is highly significant, its quantitative value is quite small, a result that is consistent with other studies showing that the static gains of trade liberalization may not be too great.

The estimates show an important positive effect of the rest of the economy upon agriculture. This large effect may, however, be affected by biases due to omitted variables that could exert similar effects upon agricultural and non-agricultural GDP. The FE estimators do control for the impact of fixed omitted variables that are country-specific, but not for shocks that happen over time and that could influence the dependent variable and be correlated with the explanatory variable. We have also used instruments that could at least deal with reverse causality biases, but certainly the issue of time-varying omitted variables remains. ${ }^{24}$ In any case, it appears that the performance of the non-agricultural sector also positively affects agriculture, as hypothesized by Gardner (2003), for example. A final important feature about the FE and RE estimates is their mutual consistency. The method of estimation selected makes little difference in the sign, statistical significance, and even the size of the coefficients.

\footnotetext{
${ }^{24}$ In the annual estimates reported below we do control for time -varying shocks that have similar effects across countries. As will be seen, this reduces the value of the coefficient, but the effect remains statistically significant.
} 
"Short-run" estimates: The static model. Table 3 present s estimates of agricultural per capita GDP using annual data using RE and FE with robust standard errors. We tried various lag structures for the explanatory variables. The results are robust to the method of estimation and to other changes in specification. The sign pattern of the coefficients does not change, though their sizes and standard errors are mildly affected by the actual lags used. We present in Table 3 the estimates using one-year lags for the explanatory variables.

The fact that now we have many more observations allows us to use annual time dummy variables in the regressions. The time dummies control for unobserved common-to-the-countries shocks that vary over time. ${ }^{25}$ The pattern of significance of the estimated coefficients and their signs are highly consistent with the "long-run" estimates reported earlier. Consistent with the short-run/long-run interpretation, in general the elasticity estimates using annual data have lower absolute values than the coefficients estimated using the five-year averages.

In particular, the effects of total government expenditures in rural areas are still positive and statistically significant, but their values are about 50\% lower than the values estimated using five-year averages. Similarly, the share of government subsidies in total expenditures is now negative and significant, as before, but the estimates are smaller in absolute value. Still, the message is the same: total government expenditures are important in promoting agricultural income, but the structure of public expenditures is even more important. Switching resources from subsidies to public goods can be an extraordinarily effective instrument to achieve faster agricultural growth.

The reduction of the size of the effect of the non-agriculture income is even more pronounced than that of the public expenditures variables. In fact, the effect of non-agriculture GDP falls by about $66 \%$ when annual data is used compared to five-year averages, though the coefficient is still significant. This drastic reduction in the size of this coefficient may reflect not only the short-run/long-run dichotomy, but also a possible reduction of the size of the omitted variable biases caused by the fact that we now partially control for effects of omitted variables that do change over time. In any case, an elasticity of about 0.13 still reflects a sizable positive impact of the rest of the economy upon agriculture.

\footnotetext{
${ }^{25}$ Both the two-way FE and RE estimates passed the White's test of heteroscedasticity at the 5\% level of statistical significance.
} 
The Dynamic Estimates. Table 4 presents the Arellano-Bond one-step procedure GMM (heteroskedastic consistent) estimates of the per capita agricultural GDP function. Although the GMM procedure has the advantage over the static estimates of accounting for the inertia that is likely to exist in the determination of agricultural GDP and in mitigating potential endogeneity biases of the explanatory variables, it also has some disadvantages. In particular, the ArellanoBond estimates tend to have low efficiency and, while first-order autocorrelation is expected, if second-order autocorrelation exists it may lead to inconsistent estimates.

The estimates in Table 4 suggest that per capita agricultural GDP adjusts relatively fast, taking about two years to complete the adjustment to changing exogenous variables. The estimates concerning the level and composition of government expenditures are highly consistent with the static ones presented earlier. The sign pattern and significance and the relative magnitudes of the total public expenditures vis-à-vis the share of expenditures in subsidies is the same as in the static estimators. A problem with the GMM estimates in Table 4 is that they fail to pass the second-order autocorrelation test. This of course may lead to inconsistent estimators.

When we normalize the variables by land area, however, the resulting estimates are free from second-order autocorrelation. These estimates are shown in Table 5, where for comparison purposes we also include the land normalized RE and FE static estimators as well. We now cannot reject the hypothesis of no second-order autocorrelation, even at low significance levels. Moreover, the Sargan test for the validity of the instruments (a test of the hypothesis that the instrumental variables are uncorrelated with the residuals) is passed, meaning that the instruments are acceptable.

The implicit long-run elasticities (that is, the steady state effects) are obtained assuming that per capita agricultural GDP does not change over time. Given that the coefficient of the lagged dependent variable coefficient is about 0.52 , the implicit long-run elasticity of total government expenditures is about $0.097(0.047 /(1-0.52))$, while the absolute value of the elasticity of the share of expenditures in non-social subsidies is almost three times bigger, equal to -0.26 . These long-run estimates obtained using the Arellano-Bond dynamic approach are similar to the corresponding long-run estimates obtained using 5-year averages static random effects method, which were 0.055 and -0.228 (reported in Table 2). This high degree of 
consistency among estimates obtained using very different approaches suggests that the estimates are robust. ${ }^{26}$

Rural poverty. The quantitative analysis of the impact of the level and structure of public expenditures on rural poverty is hampered by insufficient availability of rural poverty estimates for the countries considered and especially by issues of data quality and comparability. The definition of the poverty line especially among countries and also over time varies a lot. This may increase the "noise" affecting head count poverty measures. In addition, there are only two or at most three observations by country, a fact that considerably limits the scope of the econometric analysis. To increase the number of observations we were able to include three new countries-Guatemala, Colombia, and Nicaragua-for which we were able to obtain two poverty observations each, but restricted to the latter 6 or 7 years of the period, and for which measures over the same part of the period were available for the other variables (although we missed Uruguay from the old sample due to lack of rural poverty measures).

The use of per capita income of the poor instead of poverty rate in part deals with the problem associated with a lack of definition of a consistent poverty line. In fact the estimates appear much more precise when we use per capita income of the poor instead of poverty rate as the dependent variable. ${ }^{27}$ Table 6 shows the estimates of the determinants of per capita income of the poorest $40 \%$ of the rural population for the period 1990-2002, which is the period for which such income is measured. The data on income of the poor is not annual, but rather consists of no more than three observations per country for different years during the period 1990-2002. We estimate the income of the poor function using average lagged values of the explanatory variables over the previous 4 years of the observation. ${ }^{28}$ This is supposed to capture the delayed effect of the explanatory variables on the per capita income of the poor.

The main finding in Table 6 is that both the level of rural public expenditure and its composition show statistically significant coefficients. Public expenditures contribute to increase the income of the rural poor modestly, while the composition of public expenditures has a larger effect. Altering the composition of public spending from subsidies to public goods can cause a

\footnotetext{
${ }^{26}$ Both the GMM and RE coefficients associated with total government expenditures and share of non-social subsidies were robust to changes in the sample as well. We experimented by removing from the sample one country at a time and one year of data at a time. The sign and significance pattern was not affected and though the size of the coefficients did change, their relative sizes changed little. These regressions are available from the author on request.

27 The estimates using poverty rate as a dependent variable are available from the author.

${ }^{28} \mathrm{We}$ also tried 3 and 5 year average, but the result changed little.
} 
large increase in the income of the poor. This result is suggestive, but one should be cautious because the data base for this analysis is weak and the number of observations is low.

Agricultural land expansion. One of the most negative environmental impacts of agriculture is its effect on deforestation. Agricultural expansion into forested areas has been found to be an important direct cause of deforestation, particularly in tropical countries (Pfaff, 1999, Chomitz and Thomas, 2003). In land-rich countries agricultural growth has been based more on extending the land area rather than on the intensification of production in already cultivated lands (Abdelgalil and Cohen, 2001; Foster, Rosenzweig, and Behrman, 2002). The impact of agricultural expansion on deforestation is particularly large because of a land multiplier effect: According to empirical analyses, one additional permanent hectare of land cultivated requires clearing of between 4 and 5 hectares of forests (Chomitz and Thomas, 2003; López, 1997). This sizable land use multiplier is due to the fact that one additional permanent hectare of land cultivated needs more infrastructure and more land for human settlements, and the new land cultivated is often incorporated into a shifting cultivation cycle (to maintain one hectare under cultivation in shifting cultivation typically needs intervening at 3 to 5 hectares).

Table 7 shows the two-way FE and RE estimates of agriculture land. We explain agricultural land area using agricultural GDP, non-agricultural GDP, total public expenditures in the rural sector, the share of government subsidies in total rural public expenditures, and the index of trade openness. We normalize all variables except the last two by the rural population. To avoid problems of simultaneous equation biases affecting the per capita agricultural GDP explanatory variable, we use lagged values of per capita agriculture GDP in Table 7 (alternatively various instrumental variables were used, but the results do not dramatically change). In general the coefficient estimates are quite robust to changes in specification and the FE and RE estimators are remarkably similar.

Not surprising, agriculture GDP is an important determinant of the land area. The GDP elasticity has a value of about 0.30 , which is highly significant. This relatively low value of the GDP elasticity suggests that agricultural growth in principle does not need to necessarily rely on large area expansion. There are factors other than GDP growth that are at play. Another important result in Table 7 is that more trade openness is a factor that contributes to intensify agriculture. This effect is also highly significant. This suggests that in the countries considered 
trade openness shifts the structure of incentives toward agricultural products that are less landdemanding and perhaps more labor-intensive.

The most important finding for us is, however, the strong effect that changing the composition of public rural expenditures can cause. In fact, according to the estimates, reducing the proportion of subsidies in total public expenditures from $50 \%$ to just $40 \%$ may cause, ceteris paribus, a reduction of agricultural land area of more than $2 \%$, with the consequent reduction of the pressure imposed by agriculture on the remaining forests. As Bulte, Damania, and López (2004) have shown, land expansion is an important instrument to elicit subsidies from governments in exchange for bribes or other political contributions paid by wealthy farmers to government politicians. For a variety of reasons discussed by Bulte, Damania, and López, the ability of farmers to lobby governments and the effectiveness of such lobbying in eliciting subsidies is related to their land size. Therefore, excessively expanding agricultural land when governments are prone to subsidize the wealthy is privately rational but socially costly. The empirical results found give support to this hypothesis.

\section{Conclusion}

This paper has provided evidence suggesting that the structure of public expenditures is an important factor of economic development. The quantitative importance of this factor appears to be greater than the traditional factors on which the development literature focuses. In particular, expanding total public expenditures in rural areas while maintaining the existing public expenditure composition prevailing in the countries does little to promote agricultural income and reduce rural poverty. The key issue is not so much how much money is spent in the sector but rather how public monies are being spent. Spending a significant share of government resources in non-social subsidies causes not only less agriculture income but also induces an excessive reliance of agricultural growth on land expansion, thus possibly exacerbating the negative effects of agriculture on the remaining forests.

The econometric results provide estimates that suggest that governments over-spend in mostly politically motivated private goods and subsidies and under-spend in public goods and anti-poverty programs. Though the very large estimated effects of expenditure composition may be surprising to some, one should note that these estimates are highly consistent with two previous pieces of evidence available in the literature. First, the literature reports extremely large rates of return to many forms of public goods (often $25 \%$ to $60 \%$ per annum and above), 
including $\mathrm{R} \& \mathrm{D}$, education, health care, some infrastructure, and certain environmental protection investments, and others. Also, those studies that have performed analyses over time generally find that the rates of return show no tendency to decline over time. Recent surveys of this literature, cited earlier in the text, find an amazing degree of consensus on the estimated rates of return obtained in many studies that evaluate rates of return to public goods around the world. The fact that the studies reviewed have used different approaches and diverse data bases and have been applied to a large number of countries around the world means that this consensus should be taken seriously. These extremely high and non-declining rates of return suggest that there are important investment opportunities in public goods that are not being fully exploited. That is, it suggests under-spending in public goods.

Second, many firm-level studies around the world (some cited earlier in the text) have found that subsidies aimed at promoting investment, employment, and growth do not achieve these objectives. In some cases they are counterproductive to these goals. Thus, while the rates of return to public goods are very high, the rates of return to private goods or subsidies are very low or even negative. Yet governments tend to spend a large share of their resources on the goods that have low returns while at the same time forego ing investments with very large rates of return. Switching spending priorities can obtain massive dividends. 


\section{References}

Abdelgalil, A.E., and S.I. Cohen (2001). 'Policy Modelling of the Trade-off Between Agricultural Development and Land Degradation - the Case of Sudan'. Journal of Policy Modelling, 23, 847-874.

Alston, J., M. Marra, P. Pardey, and P. Wyatt (2000). "Research Return Redux: A Meta-Analysis and the Returns of R\&D”. Australian Journal of Agricultural Economics, 44, 1364-85.

Arellano, M., and S. Bond (1991). "Some Test of Specification for Panel Data: Monte Carlo Evidence and an Application to Employment Equations" The Review of Economic Studies 58, 277-97.

Barbier, E. (2004). "Natural Capital Resource Dependency, and Poverty in Developing Countries: The Problem of Dualism within Dualism", in R. López, J. Stiglitz and M. Toman (eds.) Sustainable Development: New Options and Policies, Oxford University Press, forthcoming

Bergstrom, F. (1998). "Capital Subsidies and the Performance of Firms," Stockholm School of Economics, Working Paper \#285

Bregman, A., M. Fuss, and H. Regev (1999). "Effects of Capital subsidization on Productivity in Israeli Industry". Bank of Israel Economic Review, 77-101

Bulte, E., R. Damania, and R. López(2004). “ On the Gains of Committing to Inefficient Production: Lobbying and Low Agricultural Productivity in Latin America", in http://www.arec.umd.edu/rlopez/govdev.

Calmon, P. (2004). "Evaluation of Subsidies in Brazil", Unpublished, The World Bank, Washington, DC.

Chomitz, K. and T. Thomas. (2003). "Determinants of Land Use in Amazonia: A Fine-Scale Spatial Analysis." American Journal of Agricultural Economics 85 (4): 1016-28.

Chu, K., H. Davoodi, and S. Gupta. (2000). "Income Distribution and Tax and Government Social Spending Policies in Developing Countries”, United Nations University, Working Paper \# 214, Helsinki.

Deacon, R. (2002). "Dictatorship, Democracy, and the Provision of Public Goods", Dept. of Economics, U. of California, San Diego.

Estache, A., and Gaspar, V. (1995). "Why tax Incentives do not Promote Investment in Brazil. In A. Shah (Ed.), Fiscal Incentives for Investment and Innovation. Baltimore: Oxford University Press. 
Fakin, B. (1995). "Investment Subsidies During Transition," Eastern European Economics, Sept./Oct.

Fan, S., P. Hazell and S. Thorat, (2000). "Government Spending, Growth and Poverty in Rural India” AJAE, 82: 1038-1051

Foster, A., M. Rosenzweig, and J. Behrman (2002). "Population Growth, Income Growth and Deforestation: Management of Village Common Land in India." Mimeo, Brown University.

Gardner, B. (2003). "Causes of Rural Economic Development", Elmhirst Lecture, Conference of the International Association of Agricultural Economists, Durban, S. Africa.

Graham, D., H. Gauthier and J.R. Mendonça de Barros, (1987). Thirty Years of Agricultural Growth in Brazil: Crop Performance, Regional Profile and Recent Policy Review, Economic Development and Cultural Change 36: 1-33

Greene, W. (2003). Econometric Analysis. Prentice Hall, New Jersey.

Harris, R. (1991). "The Employment Creation Effects of Factor Subsidies: Some Estimates for Northern Ireland". Journal of Regional Science 31:49-64.

Kerrigan, G. (2001). “Gasto Público hacia el Sector Agricola y Desarrollo de Areas Rurales",Seminario Gestión del Gasto Público para el desarrollo Agricola y rural en America Latina y el Caribe, Santiago, Chile, August.

Krueger, A., Schiff, M. and A. Valdés (1991) eds. Political Economy of agricultural Pricing Policy. Baltimore, Johns Hopkins University Press.

Lee, J. (1996). “Government Interventions and Productivity Growth” 1:392-415

López, R. (1997). "Environmental Externalities in Traditional Agriculture and the Impact of Trade Liberalization: The Case of Ghana." Journal of Development Economics 53 (1): 17-39.

López, R. and A. Valdés (2000). Rural poverty in Latin America, MacMillan Publisher, UK and Saint Martin's Press, USA.

Nerlove, M. (2002). Essays in Panel Data Econometrics. Cambridge University Press, New York, NY

Olson, M. (1965). The logic of collective action: Public goods and the theory of groups, Cambridge, MA: Harvard University Press.

Pfaff, A. (1999). "What Drives Deforestation in the Brazilian Amazon?" Journal of Environmental Economics and Management 37: 26-43. 
Pritchett, L. (1996). “Measuring Outward Orientation in LDCs: Can It Be Done?" Journal of Development Economics v.49: 307-335.

Psacharopoulos, G. (1994). "Returns to Investment in Education: A Global Update". World Development, 22(9), 1325-1343

The World Bank (2000). The Quality of Growth. Oxford University Press, Washington, DC.

The World Bank (2004). Inequality in Latin America: Breaking With History?. The World Bank, Washington DC 
TABLE 1

GOVERNMENT EXPENDITURES IN THE RURAL SECTOR: ANNUAL COUNTRY AVERAGES, 1985-2000 (MILLIONS US\$ OF 2000)

\begin{tabular}{|c|c|c|c|c|c|}
\hline Countries & Subsidies & $\begin{array}{c}\text { Subsidies as a } \\
\text { Percentage of } \\
\text { Total Expenditure } \\
(\%)\end{array}$ & $\begin{array}{l}\text { Public } \\
\text { Goods }\end{array}$ & $\begin{array}{c}\text { Public Goods } \\
\text { as a Percentage } \\
\text { of Total } \\
\text { Expenditure } \\
(\%)\end{array}$ & $\begin{array}{c}\text { Total } \\
\text { Expenditure }\end{array}$ \\
\hline Costa Rica & 41.6 & 47.4 & 46.1 & 52.6 & 87.7 \\
\hline $\begin{array}{l}\text { Dominican } \\
\text { Republic }\end{array}$ & 174.6 & 65.4 & 92.2 & 34.6 & 266.8 \\
\hline Honduras & 3.3 & 10.8 & 27.6 & 89.2 & 31.0 \\
\hline Panama & 82.9 & 80.8 & 19.6 & 19.2 & 102.5 \\
\hline Paraguay & 106.5 & 86.5 & 16.6 & 13.5 & 123.1 \\
\hline Peru & 197.3 & 55.0 & 161.4 & 45.0 & 358.7 \\
\hline Venezuela & 283.8 & 54.2 & 239.9 & 45.8 & 523.8 \\
\hline Ecuador & 89.8 & 67.3 & 43.61 & 32.7 & 133.4 \\
\hline Uruguay & 7.7 & 19.1 & 32.42 & 80.9 & 40.1 \\
\hline
\end{tabular}

Source: FAO, Regional Office for Latin America and the Caribbean 
Table 2

DETERMINANTS OF LONG-RUN PER CAPITA AGRICULTURAL GDP. DEPENDENT VARIABLE: LOG OF AVERAGE ANNUAL PER CAPITA AGRICULTURAL GDP (FIVE YEAR AVERAGES)

\begin{tabular}{|l|r|r|}
\hline \multirow{2}{*}{ Variables } & \multicolumn{2}{|c|}{ Panel Regression } \\
\cline { 2 - 3 } & Fixed Effects & Random Effects \\
\hline $\begin{array}{l}\text { Log of average annual public } \\
\text { expenditures in the rural sector }\end{array}$ & $\begin{array}{r}0.057^{* * *} \\
(0.010)\end{array}$ & $\begin{array}{r}0.055^{* * *} \\
(0.010)\end{array}$ \\
\hline $\begin{array}{l}\text { Share of non-social subsid ies in } \\
\text { expenditures }\end{array}$ & $\begin{array}{r}0.231^{* * *} \\
(0.053)\end{array}$ & $\begin{array}{r}0.228^{* * *} \\
(0.053)\end{array}$ \\
\hline Index of trade openness & $\begin{array}{r}0.002^{* * *} \\
(0.001)\end{array}$ & $0.002^{* * *}$ \\
& $0.396^{* * *}$ & $0.405^{* * *}$ \\
\hline Log of (predicted) non- & $(0.033)$ & $(0.032)$ \\
\hline agricultural per capita GDP & $2.606^{* * *}$ & $2.563^{* * *}$ \\
\hline Constant & $(0.253)$ & $(0.287)$ \\
\hline
\end{tabular}

Notes: $* * *-5 \%$ level of significance. Number of observations: 30; Number of countries: 10 
TABLE 3

ESTIMATING PER CAPITA AGRICULTURAL GDP USING ANNUAL DATA W ITH ANNUAL DUMMIES. DEPENDENT VARIABLE: LOG OF PER CAPITA AGRICULTURAL GDP

\begin{tabular}{|c|c|c|}
\hline \multirow[t]{2}{*}{ Variables } & \multicolumn{2}{|c|}{ Panel Regression } \\
\hline & Fixed Effects & Random Effects \\
\hline $\begin{array}{l}\text { Log of total per capita public } \\
\text { expenditures in the rural sector }\end{array}$ & $\begin{array}{r}0.031^{* * * *} \\
(0.009) \\
\end{array}$ & $\begin{array}{r}0.028 * * * \\
(0.009) \\
\end{array}$ \\
\hline $\begin{array}{l}\text { Share of expenditures on non-social } \\
\text { subsidies in expenditures }\end{array}$ & $\begin{array}{r}-0.117 * * * \\
(0.052) \\
\end{array}$ & $\begin{array}{r}-0.10 * * * \\
(0.050) \\
\end{array}$ \\
\hline Index of trade openness & $\begin{array}{r}0.002 * * * \\
(0.001) \\
\end{array}$ & $\begin{array}{r}0.002 * * * \\
(0.001) \\
\end{array}$ \\
\hline $\begin{array}{l}\text { Log of (predicted) per capita non- } \\
\text { agriculture GDP }\end{array}$ & $\begin{array}{r}0.133 * * * \\
(0.042) \\
\end{array}$ & $\begin{array}{r}0.140 * * * \\
(0.042) \\
\end{array}$ \\
\hline Land Area in agriculture & $\begin{array}{r}0.851 * * * \\
(0.129) \\
\end{array}$ & $\begin{array}{r}0.712 * * * \\
(0.105) \\
\end{array}$ \\
\hline Constant & $\begin{array}{r}4.804 * * * \\
(0.788) \\
\end{array}$ & $\begin{array}{r}3.98^{* * *} \\
(0.687) \\
\end{array}$ \\
\hline D85 & $\begin{array}{r}-0.245^{* * * *} \\
(0.039) \\
\end{array}$ & $\begin{array}{r}-0.245^{* * *} \\
(0.039) \\
\end{array}$ \\
\hline D86 & $\begin{array}{r}-0.213^{* * *} \\
(0.038) \\
\end{array}$ & $\begin{array}{r}-0.214 * * * \\
(0.037) \\
\end{array}$ \\
\hline D87 & $\begin{array}{r}-0.210 * * * \\
(0.037) \\
\end{array}$ & $\begin{array}{r}-0.212 * * * \\
(0.036) \\
\end{array}$ \\
\hline D88 & $\begin{array}{r}-0.169 * * * \\
(0.036) \\
\end{array}$ & $\begin{array}{r}-0.171^{* * *} \\
(0.035) \\
\end{array}$ \\
\hline D89 & $\begin{array}{r}-0.160^{* * * *} \\
(0.036) \\
\end{array}$ & $\begin{array}{r}-0.162 * * * \\
(0.035) \\
\end{array}$ \\
\hline D90 & $\begin{array}{r}-0.167 * * * \\
(0.037) \\
\end{array}$ & $\begin{array}{r}-0.167 * * * \\
(0.037) \\
\end{array}$ \\
\hline D91 & $\begin{array}{r}-0.145^{* * *} * \\
(0.036) \\
\end{array}$ & $\begin{array}{r}-0.143 * * * \\
(0.034) \\
\end{array}$ \\
\hline D92 & $\begin{array}{r}-0.133^{* * *} \\
(0.035) \\
\end{array}$ & $\begin{array}{r}-0.132 * * * \\
(0.035) \\
\end{array}$ \\
\hline D93 & $\begin{array}{r}-0.149 * * * \\
(0.031) \\
\end{array}$ & $\begin{array}{r}-0.149 * * * \\
(0.031) \\
\end{array}$ \\
\hline D94 & $\begin{array}{r}-0.109 * * * \\
(0.031) \\
\end{array}$ & $\begin{array}{r}-0.109 * * * \\
(0.031) \\
\end{array}$ \\
\hline D95 & $\begin{array}{r}-0.070^{* * * *} \\
(0.030) \\
\end{array}$ & $\begin{array}{r}-0.070 * * * \\
(0.030) \\
\end{array}$ \\
\hline D96 & $\begin{array}{r}-0.030 \\
(0.030) \\
\end{array}$ & $\begin{array}{r}-0.029 \\
(0.029) \\
\end{array}$ \\
\hline D97 & $\begin{array}{r}-0.025 \\
(0.030) \\
\end{array}$ & $\begin{array}{r}-0.025 \\
(0.030) \\
\end{array}$ \\
\hline D98 & $\begin{array}{r}-0.022 \\
(0.029) \\
\end{array}$ & $\begin{array}{r}-0.022 \\
(0.029) \\
\end{array}$ \\
\hline D99 & $\begin{array}{r}-0.010 \\
(0.029) \\
\end{array}$ & $\begin{array}{r}-0.010 \\
(0.029) \\
\end{array}$ \\
\hline
\end{tabular}

Number of observations: 133; Number of countries (groups): 10 
TABLE 4

DYNAMIC ARELLANO-BOND GMM ESTIMATES OF PER CAPITA AGRICULTURAL GDP. DEPENDENT VARIABLE: LOG OF PER CAPITA AGRICULTURAL GDP

\begin{tabular}{|c|c|c|}
\hline Variables & $\begin{array}{c}\text { Model } \\
1 \\
\end{array}$ & $\begin{array}{c}\text { Model } \\
2 \\
\end{array}$ \\
\hline Lag of log of per capita agricultural GDP & $\begin{array}{l}0.520^{* * * *} \\
(0.194)\end{array}$ & $\begin{array}{l}0.551^{* * * *} \\
(0.199)\end{array}$ \\
\hline $\begin{array}{l}\text { Log of total per capita public expenditures } \\
\text { in the rural sector }\end{array}$ & $\begin{array}{l}0.022 * * \\
(0.012) \\
\end{array}$ & $\begin{array}{l}0.027 * * * \\
(0.011)\end{array}$ \\
\hline $\begin{array}{l}\text { Share of expenditures on non-social } \\
\text { subsidies in total expenditures }\end{array}$ & $\begin{array}{l}-0.075 * * \\
(0.041)\end{array}$ & $\begin{array}{l}-0.090 * * * \\
(0.042)\end{array}$ \\
\hline Index of trade openness & $\begin{array}{r}0.001 \\
(0.001) \\
\end{array}$ & $\begin{array}{l}0.0003 \\
(0.001) \\
\end{array}$ \\
\hline Log of non-agriculture GDP & $\begin{array}{r}0.156 \\
(0.116) \\
\end{array}$ & $\begin{array}{r}0.136 \\
(0.087) \\
\end{array}$ \\
\hline Log of land area in agriculture & $\begin{array}{r}0.202 \\
(0.222) \\
\end{array}$ & $\begin{array}{r}0.212 \\
(0.223) \\
\end{array}$ \\
\hline Constant & $\begin{array}{r}0.003 \\
(0.005) \\
\end{array}$ & $\begin{array}{r}0.002 \\
(0.005) \\
\end{array}$ \\
\hline D87 & & $\begin{array}{r}-0.034 \\
(0.053) \\
\end{array}$ \\
\hline $\bar{D} 88$ & & $\begin{array}{l}0.042 * * * \\
(0.019)\end{array}$ \\
\hline D89 & & $\begin{array}{r}0.002 \\
(0.028)\end{array}$ \\
\hline D90 & & $\begin{array}{r}-0.014 \\
(0.031) \\
\end{array}$ \\
\hline D91 & & $\begin{array}{r}0.012 \\
(0.026) \\
\end{array}$ \\
\hline D92 & & $\begin{array}{r}-0.004 \\
(0.038) \\
\end{array}$ \\
\hline D93 & & $\begin{array}{r}-0.016 \\
(0.037)\end{array}$ \\
\hline D94 & & $\begin{array}{r}0.005 \\
(0.034) \\
\end{array}$ \\
\hline D95 & & $\begin{array}{r}0.022 \\
(0.026) \\
\end{array}$ \\
\hline D96 & & $\begin{array}{r}0.026 \\
(0.025) \\
\end{array}$ \\
\hline D97 & & $\begin{array}{r}0.004 \\
(0.017) \\
\end{array}$ \\
\hline D98 & & $\begin{array}{r}0.004 \\
(0.023) \\
\end{array}$ \\
\hline D99 & & $\begin{array}{r}0.007 \\
(0.020) \\
\end{array}$ \\
\hline $\begin{array}{l}\text { Arellano-Bond test autocovariance in } \\
\text { residuals of order } 2\end{array}$ & $1.82 * *$ & $1.96^{* * *}$ \\
\hline
\end{tabular}

Notes: $* * * 5 \%$, ** 10\%, level of significance. Number of observations: 129; Number of countries (groups): 10. All standard errors are robust. 
Table 5

ESTIMATINGAGRICULTURAL GDP NORMALIZED BY LAND AREA, 1985-2000.

\begin{tabular}{|c|c|c|c|}
\hline \multirow[t]{2}{*}{ Variables } & \multirow{2}{*}{$\begin{array}{l}\text { Generalized Method of } \\
\text { Moments }\end{array}$} & \multicolumn{2}{|c|}{ Panel Regression } \\
\hline & & Fixed Effects & Random Effects \\
\hline Lag of agricultural GDP per hectare & $\begin{array}{r}0.522 * * * \\
(0.099)\end{array}$ & & \\
\hline $\begin{array}{l}\text { Log of total public expenditures in rural } \\
\text { areas (normalized by land area) }\end{array}$ & $\begin{array}{r}0.047 * * * \\
(0.014)\end{array}$ & $\begin{array}{r}0.031 * * * \\
(0.009)\end{array}$ & $\begin{array}{r}0.032 * * * \\
(0.009)\end{array}$ \\
\hline $\begin{array}{l}\text { Share of non-social subsidies in total } \\
\text { expenditures }\end{array}$ & $\begin{array}{r}-0.120 * * * \\
(0.059)\end{array}$ & $\begin{array}{r}-0.119 * * * \\
(0.048)\end{array}$ & $\begin{array}{r}-0.123 * * * \\
(0.049)\end{array}$ \\
\hline Index of trade openness & $\begin{array}{r}0.001 \\
(0.001)\end{array}$ & $\begin{array}{r}0.002 * * * \\
(0.001)\end{array}$ & $\begin{array}{r}0.002 * * * \\
(0.001)\end{array}$ \\
\hline Log of per capita non-agriculture GDP & $\begin{array}{r}0.085 \\
(0.056)\end{array}$ & $\begin{array}{r}0.140 * * * \\
(0.044)\end{array}$ & $\begin{array}{r}0.162 * * * \\
(0.043)\end{array}$ \\
\hline Constant & $\begin{array}{r}0.004 \\
(0.004)\end{array}$ & $\begin{array}{r}4.662 * * * \\
(0.346)\end{array}$ & $\begin{array}{r}4.515 * * * \\
(0.383)\end{array}$ \\
\hline D85 & & $\begin{array}{r}-0.245^{* * *} \\
(0.039)\end{array}$ & $\begin{array}{r}-0.234 * * * \\
(0.039)\end{array}$ \\
\hline$\overline{\mathrm{D} 86}$ & & $\begin{array}{r}-0.211 * * * \\
(0.038)\end{array}$ & $\begin{array}{r}-0.201 * * * \\
(0.038)\end{array}$ \\
\hline$\overline{\mathrm{D} 87}$ & $\begin{array}{r}-0.028 \\
(0.030)\end{array}$ & $\begin{array}{r}-0.208 * * * \\
(0.037)\end{array}$ & $\begin{array}{r}-0.197 * * * \\
(0.037)\end{array}$ \\
\hline D88 & $\begin{array}{r}0.047 * * \\
(0.028)\end{array}$ & $\begin{array}{r}-0.167 * * * \\
(0.036)\end{array}$ & $\begin{array}{r}-0.157 * * * \\
(0.036)\end{array}$ \\
\hline$\overline{\mathrm{D} 89}$ & $\begin{array}{r}0.013 \\
(0.028)\end{array}$ & $\begin{array}{r}-0.158^{* * * *} \\
(0.036)\end{array}$ & $\begin{array}{r}-0.149 * * * \\
(0.036)\end{array}$ \\
\hline$\overline{\mathrm{D} 90}$ & $\begin{array}{r}-0.016 \\
(0.028)\end{array}$ & $\begin{array}{r}-0.166^{* * *} \\
(0.037)\end{array}$ & $\begin{array}{r}-0.156 * * * \\
(0.037)\end{array}$ \\
\hline$\overline{\mathrm{D} 91}$ & $\begin{array}{r}0.007 \\
(0.027)\end{array}$ & $\begin{array}{r}-0.143 * * * \\
(0.036)\end{array}$ & $\begin{array}{r}-0.134 * * * \\
(0.036)\end{array}$ \\
\hline$\overline{\mathrm{D} 92}$ & $\begin{array}{r}-0.011 \\
(0.028)\end{array}$ & $\begin{array}{r}-0.132 * * * \\
(0.035)\end{array}$ & $\begin{array}{r}-0.124 * * * \\
(0.035)\end{array}$ \\
\hline$\overline{\mathrm{D} 93}$ & $\begin{array}{r}-0.028 \\
(0.025)\end{array}$ & $\begin{array}{r}-0.147 * * * \\
(0.032)\end{array}$ & $\begin{array}{r}-0.142 * * * \\
(0.032)\end{array}$ \\
\hline D94 & $\begin{array}{r}0.005 \\
(0.025)\end{array}$ & $\begin{array}{r}-0.107 * * * \\
(0.032)\end{array}$ & $\begin{array}{r}-0.102 * * * \\
(0.032)\end{array}$ \\
\hline D95 & $\begin{array}{r}0.020 \\
(0.025) \\
\end{array}$ & $\begin{array}{r}-0.069 * * * \\
(0.030) \\
\end{array}$ & $\begin{array}{r}-0.066^{* * * *} \\
(0.031) \\
\end{array}$ \\
\hline D96 & $\begin{array}{r}0.027 \\
(0.025) \\
\end{array}$ & $\begin{array}{r}-0.028 \\
(0.030)\end{array}$ & $\begin{aligned}-0.025 \\
(0.030)\end{aligned}$ \\
\hline D97 & $\begin{array}{r}0.004 \\
(0.025)\end{array}$ & $\begin{array}{r}-0.025 \\
(0.030)\end{array}$ & $\begin{array}{l}-0.023 \\
(0.030)\end{array}$ \\
\hline D98 & $\begin{array}{l}-0.0003 \\
(0.026)\end{array}$ & $\begin{array}{r}-0.022 \\
(0.029)\end{array}$ & $\begin{aligned}-0.020 \\
(0.030)\end{aligned}$ \\
\hline D99 & $\begin{array}{r}0.003 \\
(0.026)\end{array}$ & $\begin{array}{r}-0.010 \\
(0.029)\end{array}$ & $\begin{array}{r}-0.009 \\
(0.030)\end{array}$ \\
\hline $\begin{array}{l}\text { Arellano-Bond test autocovariance in } \\
\text { residuals of order } 2\end{array}$ & 0.99 & & \\
\hline
\end{tabular}

Note: $* * *-5 \%$ level of significance; $* *-10 \%$ level of significance. Number of observations: 133; Number of countries: 10 . 
TABLE 6

ESTIMATING THE DETERMINANTS OF PER CAPITA INCOME OF RURAL POOR, 1990-2002*. DEPENDENT VARIABLE: LOG OF INCOME PER CAPITA OF THE 40\% POOREST IN THE RURAL SECTOR

\begin{tabular}{|c|c|c|}
\hline \multirow{2}{*}{ Variable } & \multicolumn{2}{|c|}{ Panel Regression } \\
\hline & Fixed Effects & Random Effects \\
\hline $\begin{array}{l}\text { Log of average annual public } \\
\text { expenditures per capita in the rural } \\
\text { sector }\end{array}$ & $\begin{array}{r}0.182^{* * * *} \\
(0.095)\end{array}$ & $\begin{array}{r}0.172 * * * \\
(0.087)\end{array}$ \\
\hline $\begin{array}{l}\text { Share of non-social subsid ies in } \\
\text { public expenditures in the rural } \\
\text { sector }\end{array}$ & $\begin{array}{r}-2.043 * * * \\
(0.854) \\
\end{array}$ & $\begin{array}{r}-1.967 * * * \\
(0.850) \\
\end{array}$ \\
\hline $\begin{array}{l}\text { Log of lagged agricultural GDP } \\
\text { per capita }\end{array}$ & $\begin{array}{r}-1.504 \\
(0.813) \\
\end{array}$ & $\begin{array}{r}0.148 \\
(0.367) \\
\end{array}$ \\
\hline $\begin{array}{l}\text { Log of lagged non-agricultural } \\
\text { GDP per capita }\end{array}$ & $\begin{array}{r}2.028 \\
(0.881)\end{array}$ & $\begin{array}{r}0.266 \\
(0.279)\end{array}$ \\
\hline Constant & $\begin{array}{r}1.649 * * * \\
(1.768)\end{array}$ & $\begin{array}{r}5.296 * * * \\
(0.575)\end{array}$ \\
\hline Number of countries & 12 & 12 \\
\hline Adj R-Sq & 0.742 & 0.6208 \\
\hline \# Observations & 34 & 34 \\
\hline Hausman test Chi square & & 0.056 \\
\hline
\end{tabular}

Note: * Using 5 year lagged averages for all variables but for the dependent variable. All standard errors are heteroskedastic consistent. $* * *-5 \%$ level of significance; 
Table 7.

ESTIMATING THE DETERMINANTS OF AGRICULTURAL LAND AREA FOR TEN COUNTRIES, 1985-2000.

\begin{tabular}{|c|c|c|}
\hline \multirow{2}{*}{ Variable } & \multicolumn{2}{|c|}{ Panel Regression } \\
\hline & Fixed Effects & Random Effects \\
\hline Log of lagged agricultural GDP per capita & $\begin{array}{r}0.307 * * * \\
(0.061) \\
\end{array}$ & $\begin{array}{r}0.339 * * * \\
(0.046) \\
\end{array}$ \\
\hline $\begin{array}{l}\text { Log of average annual public } \\
\text { expenditures per capita in the rural sector }\end{array}$ & $\begin{array}{r}-0.020 * * * \\
(0.006)\end{array}$ & $\begin{array}{r}-0.019 * * * \\
(0.006)\end{array}$ \\
\hline $\begin{array}{l}\text { Share of non-social subsidies in public } \\
\text { expenditures in the rural sector }\end{array}$ & $\begin{array}{r}0.119 * * * \\
(0.033)\end{array}$ & $\begin{array}{r}0.113 * * * \\
(0.030)\end{array}$ \\
\hline $\begin{array}{l}\text { Log of (predicted) non-agricultural GDP } \\
\text { per capita }\end{array}$ & $\begin{array}{r}0.028 \\
(0.026)\end{array}$ & $\begin{array}{r}0.035 \\
(0.026)\end{array}$ \\
\hline Index of trade openness & $\begin{array}{r}-0.002 * * * \\
(0.0004) \\
\end{array}$ & $\begin{array}{r}-0.002 * * * \\
(0.0004) \\
\end{array}$ \\
\hline D85 & $\begin{array}{r}0.082 * * * \\
(0.036) \\
\end{array}$ & $\begin{array}{r}0.097 * * * \\
(0.026) \\
\end{array}$ \\
\hline D86 & $\begin{array}{r}0.080 * * * \\
(0.034) \\
\end{array}$ & $\begin{array}{r}0.093 * * * \\
(0.024) \\
\end{array}$ \\
\hline D87 & $\begin{array}{r}0.071 * * * \\
(0.032) \\
\end{array}$ & $\begin{array}{r}0.084 * * * \\
(0.024) \\
\end{array}$ \\
\hline D88 & $\begin{array}{r}0.059 * * \\
(0.032) \\
\end{array}$ & $\begin{array}{r}0.071 * * * \\
(0.023) \\
\end{array}$ \\
\hline D89 & $\begin{array}{r}0.058 * * \\
(0.030) \\
\end{array}$ & $\begin{array}{r}0.069 * * * \\
(0.023) \\
\end{array}$ \\
\hline D90 & $\begin{array}{r}0.068 * * * \\
(0.031)\end{array}$ & $\begin{array}{r}0.081 * * * \\
(0.023)\end{array}$ \\
\hline D91 & $\begin{array}{r}0.061 * * * \\
(0.030) \\
\end{array}$ & $\begin{array}{r}0.071 * * * \\
(0.023) \\
\end{array}$ \\
\hline D92 & $\begin{array}{l}0.049^{*} \\
(0.031) \\
\end{array}$ & $\begin{array}{r}0.059 * * * \\
(0.022) \\
\end{array}$ \\
\hline D93 & $\begin{array}{r}0.056^{* *} \\
(0.028) \\
\end{array}$ & $\begin{array}{r}0.064 * * * \\
(0.020) \\
\end{array}$ \\
\hline D94 & $\begin{array}{l}0.042^{*} \\
(0.027) \\
\end{array}$ & $\begin{array}{r}0.048 * * * \\
(0.019) \\
\end{array}$ \\
\hline D95 & $\begin{array}{r}0.031 \\
(0.027) \\
\end{array}$ & $\begin{array}{r}0.035^{* *} \\
(0.018) \\
\end{array}$ \\
\hline D96 & $\begin{array}{r}0.012 \\
(0.028) \\
\end{array}$ & $\begin{array}{r}0.015 \\
(0.018) \\
\end{array}$ \\
\hline D97 & $\begin{array}{r}0.010 \\
(0.028) \\
\end{array}$ & $\begin{array}{r}0.012 \\
(0.018) \\
\end{array}$ \\
\hline D98 & $\begin{array}{r}0.011 \\
(0.028) \\
\end{array}$ & $\begin{array}{r}0.012 \\
(0.018) \\
\end{array}$ \\
\hline D99 & $\begin{array}{r}0.008 \\
(0.032) \\
\end{array}$ & $\begin{array}{r}0.008 \\
(0.018) \\
\end{array}$ \\
\hline Adj R-Sq & 0.999 & 0.696 \\
\hline
\end{tabular}

Note: All standard errors are heteroskedastic consistent. ***5\% level of significance; **10\% level of significance; * $15 \%$ level of significance. There are 10 countries and 153 observations. 


\section{Appendix}

\section{Summary Statistics of Selected Variables Used in the Regressions}

\begin{tabular}{|l|r|r|r|r|}
\hline \multicolumn{1}{|c|}{ Variables } & \multicolumn{1}{c|}{ Mean } & \multicolumn{1}{c|}{ Std. Dev. } & Minimum & Maximum \\
\hline $\begin{array}{l}\text { Share of non- social subsidies in public } \\
\text { expenditures in the rural sector }\end{array}$ & 0.477 & 0.264 & 0.030 & 0.920 \\
\hline Index of trade openness & -16.698 & 21.343 & -63.210 & 55.452 \\
\hline $\begin{array}{l}\text { Agricultural GDP per capita in 000s } \\
\text { 2000 dollars }\end{array}$ & 0.844 & 1.487 & 0.220 & 7.144 \\
\hline Log of agricultural GDP per capita & -0.170 & 0.789 & -1.514 & 1.966 \\
\hline $\begin{array}{l}\text { Total per capita public expenditures in } \\
\text { the rural sector in 000s dollars }\end{array}$ & 0.060 & 0.065 & 0.000 & 0.412 \\
\hline $\begin{array}{l}\text { Log of total per capita public } \\
\text { expenditures in the rural sector }\end{array}$ & -3.868 & 2.264 & -10.820 & -0.886 \\
\hline $\begin{array}{l}\text { Non-social subsidies per capita in } \\
\text { 0000s dollars }\end{array}$ & 0.033 & 0.038 & 0.001 & 0.228 \\
\hline Log of non-social subsidies per capita & -4.859 & 2.541 & -11.513 & -1.479 \\
\hline $\begin{array}{l}\text { Public goods expenditure per capita in } \\
\text { 000s dollars }\end{array}$ & 0.027 & 0.034 & 0.001 & 0.184 \\
\hline $\begin{array}{l}\text { Log of public goods expenditure per } \\
\text { capita }\end{array}$ & -4.668 & 2.212 & -11.513 & -1.691 \\
\hline $\begin{array}{l}\text { Land area in agriculture per capita in } \\
\text { 000s of hectares }\end{array}$ & 0.008 & 0.014 & 0.001 & 0.055 \\
\hline $\begin{array}{l}\text { Log of land area in agriculture per } \\
\text { capita }\end{array}$ & -5.757 & 1.260 & -7.808 & -2.898 \\
\hline $\begin{array}{l}\text { Non-agricultural GDP per capita in } \\
\text { 000s of dollars }\end{array}$ & 0.207 & 0.109 & -2.189 & 2.100 \\
\hline $\begin{array}{l}\text { Log of non-agricultural GDP per } \\
\text { capita }\end{array}$ & 1.821 & & 0.112 \\
\hline
\end{tabular}

